\title{
SOIL-WATER STORAGE PREDICTIONS FOR CULTIVATED CROPS ON THE ZÁHORSKÁ LOWLANDS
}

Miroslava JARABICOVÁ ${ }^{1 *}$, Peter MINARIČ ${ }^{1}$

\begin{abstract}
The The main objective of this paper is to evaluate the impact of climate change on the soil-water regime of the Záhorská lowlands. The consequences of climate change on soil-water storage were analyzed for two crops: spring barley and maize. We analyzed the consequences of climate change on soil-water storage for two crops: spring barley and maize. The soil-water storage was simulated with the GLOBAL mathematical model. The data entered into the model as upper boundary conditions were established by the SRES A2 and SRES B1 climate scenarios and the KNMI regional climate model for the years from 2071 to 2100 (in the text called the time horizon 2085 which is in the middle this period). For the reference period the data from the years 1961-1990 was used. The results of this paper predict soil-water storage until the end of this century for the crops evaluated, as well as a comparison of the soil-water storage predictions with the course of the soil-water storage during the reference period.
\end{abstract}

\section{Address}

1 Department of Land and Water Management, Faculty of Civil Engineering, Slovak University of Technology in Bratislava, Radlinského 11, 81005 Bratislava, Slovakia

* Corresponding author: miroslava.jarabicova@stuba.sk

\section{Key words}

- Model

- Climate scenarios,

- Time horizon,

- Climate change.

\section{INTRODUCTION}

Over the past decade, the threat of climate change and its negative impacts have been quite real, not only in Slovakia, but also worldwide. The most severe manifestation of global warming is an increase in the concentration of greenhouse gases in the atmosphere, which occurs due to human activities and technological processes. The constant increase in greenhouse gas emissions causes global warming, changes in precipitation regimes, increases in sea levels, etc. Among the consequences (Nevřelová, 2007) which have already been recorded, are for example, extreme weather changes, which are also noticeable in Slovakia, high amounts of precipitation, extreme droughts and heat waves, and the increasing intensity of tropical cyclones and storms. Scientists around the world are constantly looking for opportunities to reduce or stop the threat of global warming and thereby eliminate the negative effects of climate change. In order for the adaptation measures to be effective so that climate change does not ex- ceed a tolerable limit, the Framework Convention on Climate Change (1992) was adopted at the UN Conference on the Environment and Its Development (Rio de Janeiro). In order to best prepare for the possible threats, it is important to know possible future developments.

It was therefore decided to address climate changes in the Záhorská lowlands and their impact on soil-water storage at the locality of Jakubov, where ongoing monitoring of the soil moisture and groundwater level has been established since 2009. When analyzing the effects of climate change on soil water storage (Vitková et al., 2013; Pásztorová, 2013), a regional model was used, namely, the KNMI and two climate scenarios, namely, the SRES A2 and SRES B1 (Mind'aš et al., 2011). The reference period of 30 years was compared with the last time horizon of 2085 for the above-mentioned model and scenarios. The GLOBAL mathematical model (Majerčák et al., 1994) was used for two crops, i.e., spring barley and maize, to highlight the changes which may occur in the soil-water storage by the end of the 21 st century. 


\section{MATERIALS AND METHODS}

The impact of climate change on the soil-water regime was studied at the locality of Jakubov near the small town of Malacky, which is located in the Záhorská lowlands (as shown in Fig. 1). These lowlands belong to the area of the Vienna basin and are located in western Slovakia near its border with Austria and the Czech Republic. They are divided into the Borská nížina (lowlands) and the Chvojnická pahorkatina (uplands). The Záhorská lowlands lie between the Small Carpathian mountain range and the Morava River. In the north they are adjacent to the White Carpathian Mountains; in the east they border the Small Carpathians, while in the south and southwest, they form a border with Austria and in the northwest with the Dolnomoravský úval (valley). Their area is approximately $2,500 \mathrm{~km}^{2}$, and there are almost 300,000 inhabitants.

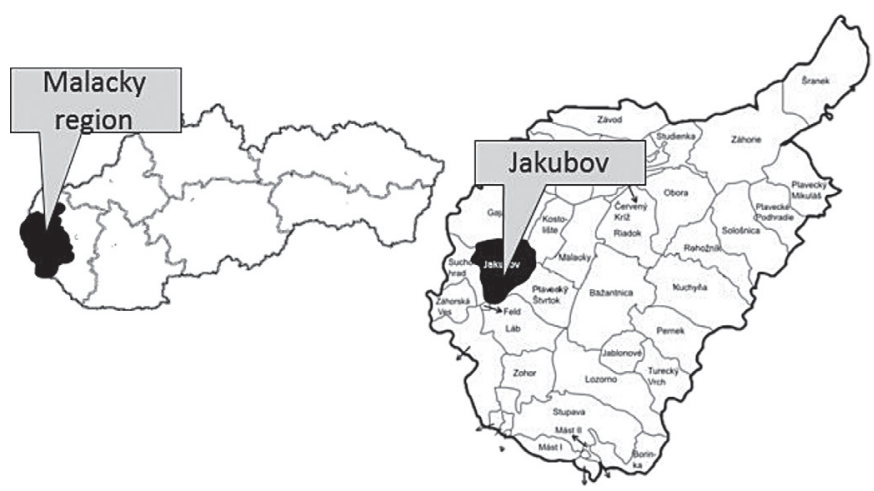

Fig. 1 The locality of Jakubov in the Záhorská lowlands in Slovakia.

The GLOBAL mathematical model (Majerčák, Novák, 1994) was selected for the soil-water storage simulation. It belongs to a group of one-dimensional models that simulate vertical soil-water flow under isothermic conditions. It is often used for soil-water simulations under the conditions in Slovakia, because of the good agreement of its results with field-observed values (Igaz et al., 2007; Majerčák, 2004). It calculates the soil moisture distribution and soil-water potential with respect to time and the initial and boundary conditions. Soil-water flow is described the Richard's equation for a one-dimensional case:

$$
\frac{\partial h_{w}}{\partial t}=\frac{1}{c\left(h_{w}\right)} \cdot \frac{\partial}{\partial z}\left[k\left(h_{w}\right) \cdot\left(\frac{\partial h_{w}}{\partial z}+1\right)\right]-\frac{S(z, t)}{c\left(h_{w}\right)}
$$

where:

$$
\begin{array}{llr}
h_{w} & \text { - soil moisture potential } & {[\mathrm{cm}],} \\
k\left(h_{w}\right) & \text { - unsaturated soil hydraulic conductivity }\left[\mathrm{cm} \cdot \mathrm{s}^{-1}\right], \\
S(z, t) & \text { - vegetation root water offtake intensity } & {\left[\mathrm{cm} \cdot \mathrm{s}^{-1}\right],} \\
C\left(h_{w}\right)=\partial \theta / \partial h_{w} & \text { - specific (unit) water capacity } & {\left[\mathrm{cm}^{-1}\right],} \\
\theta & \text { - volumetric soil moisture } & {\left[\mathrm{cm}^{3} \cdot \mathrm{cm}^{-3}\right],} \\
z & \text { - vertical ordinate } & {[\mathrm{cm}],} \\
t & \text { - time ordinate } & {[\mathrm{s}] .}
\end{array}
$$

The data entered in the GLOBAL model consist of meteorological data, the bottom boundary condition for each day, the daily canopy characteristics and the characteristics of the soil profile evaluated.

Meteorological data consists of the daily precipitation totals, the average daily air temperature, the daily totals of the duration of sunshine, the daily average atmospheric water vapor pressure and the daily average wind speed. This data is from the monitoring station in Malacky, which is the nearest Slovak Hydrometeorological Institute (SHMI) meteorological station to the area of interest in Jakubov. Based on of the meteorological data from the reference period (19611990) there was meteorological data for the evaluated period 20712100 by the CGCM 3.1 global model (it works with the pessimistically climate scenario SRES A2 and the optimistically climate scenario SRES B1) and the KNMI regional model prepared.

Soil is in the model characterized by the water retention curve (WRC) and the saturated hydraulic conductivity. For this purpose, intact soil samples were collected in the Záhorská lowlands. With these samples, laboratory analysis was made. Points of drainage branch of the WRC were measured. These points were further approximated according to Van Genuchten (1978) and parameters $\alpha$ and $n$ that were entered into the model were found. Saturated hydraulic conductivity was measured on variable hydraulic gradient equipment. Soil parameters used, that were entered into the GLOBAL model, are shown in Table 1.

The ground water level inputs to the GLOBAL model, is a bottom boundary condition. Since 2009 the monitoring GWL has been carried out at the Jakubov Site. Based on the data from the SHMI Jakubov station and monitoring data from field measurements of GWL, the dependence was detected, which was used to determine the location of the GWL throughout the reviewed period.

The next input in the GLOBAL model is canopy characteristics (tab. 2), which consists of the leaf area index LAI, the evaporating surface roughness, the albedo of the evaporating surface (reflection coefficient of solar radar), the depth of the root zone.

Tab. 2 Input characteristics for compared canopies (max. values).

\begin{tabular}{|c|c|c|}
\cline { 2 - 3 } \multicolumn{1}{c|}{} & MAIZE & SPRING BARLEY \\
\hline $\begin{array}{c}\text { Specific interception capacity } \\
\left(\mathbf{v}_{\text {wind }}=\mathbf{0}\right)[\mathbf{m m}]\end{array}$ & 0.68 & 0.6 \\
\hline LAI $\left[\mathbf{m}^{2} \cdot \mathbf{m}^{-2}\right]$ & 3.0 & 3.6 \\
\hline Coverage relative $\left[\mathbf{m}^{2} \cdot \mathbf{m}^{-2}\right]$ & 0.8 & 0.9 \\
\hline
\end{tabular}

The GLOBAL model provides a large spectrum of daily and cumulative outputs from which its evaluation of soil-water storage in the chosen soil layer is the most important for the research.

Tab. 1 Physical and hydrophysical characteristics of soil used by simulation ( $\alpha, n$-Van Genuchtens parameters of WRC, $\theta_{s}-$ water content at saturation, $\theta_{r}$ - residual soil water content, $K$ - saturated hydraulic conductivity).

\begin{tabular}{|c|c|c|c|c|c|}
\hline Sampling depth $[\mathbf{c m}]$ & $\begin{array}{c}\boldsymbol{\alpha} \\
{\left[\mathbf{c m}^{-1}\right]}\end{array}$ & $\begin{array}{c}\mathbf{n} \\
{[-]}\end{array}$ & $\begin{array}{c}\boldsymbol{\theta}_{\mathbf{s}} \\
{\left[\mathbf{c m}^{\mathbf{3}} \cdot \mathbf{c m}^{-3}\right]}\end{array}$ & $\begin{array}{c}\boldsymbol{\theta}_{\mathbf{r}} \\
{\left[\mathbf{c m}^{\mathbf{3}} \cdot \mathbf{c m}^{-3}\right]}\end{array}$ & $\begin{array}{c}\mathbf{K} \\
{\left[\mathbf{c m}^{-\mathbf{1}} \mathbf{]}\right.}\end{array}$ \\
\hline $0-25$ & 0.0306 & 1.0976 & 0.4833 & 0.0641 & 49.41 \\
\hline $25-75$ & 0.0578 & 1.0856 & 0.4441 & 0.0610 & 46.10 \\
\hline$>75$ & 0.1786 & 1.1046 & 0.4877 & 0.0581 & 55.52 \\
\hline
\end{tabular}




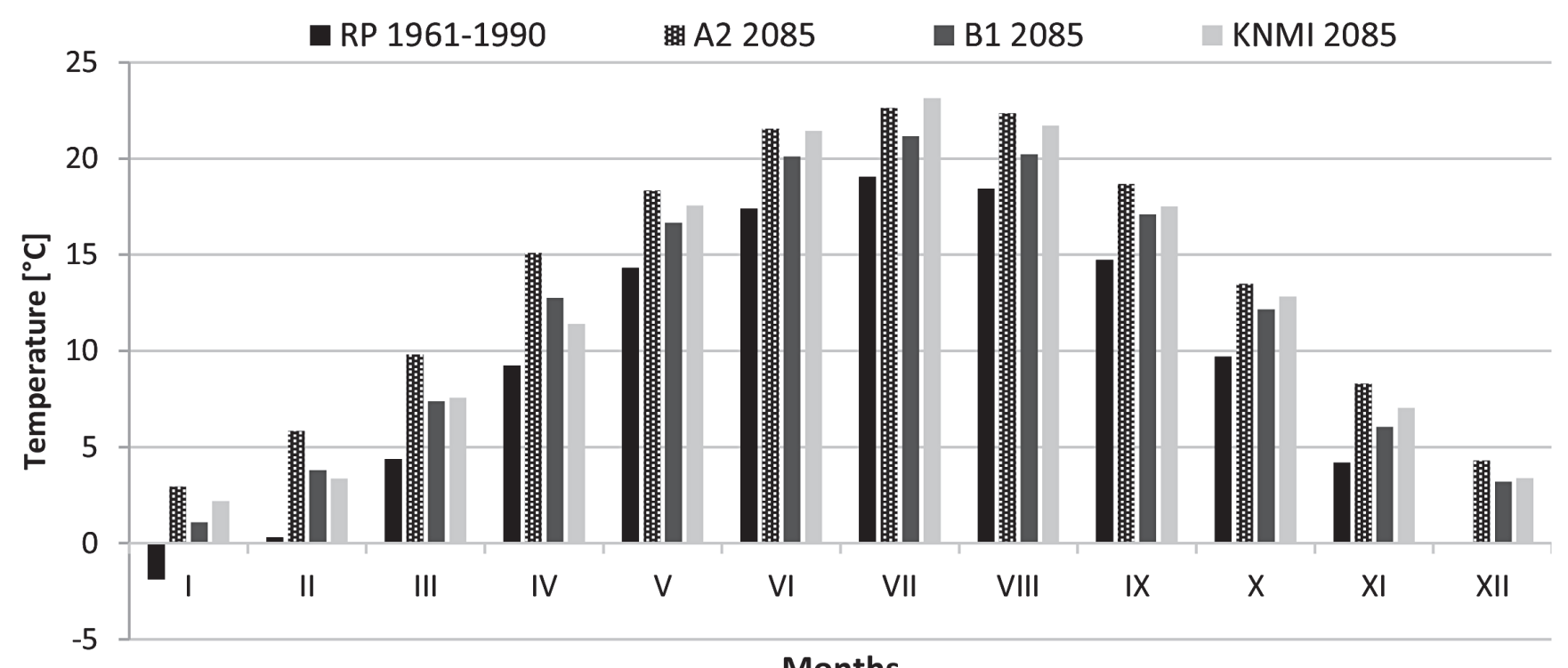

Months

Fig. 2 Comparison of the average monthly temperature in the time horizon 2085 for the SRES A2 and SRES B1 scenarios and KNMI model with the reference period (RP) 1961-1990.

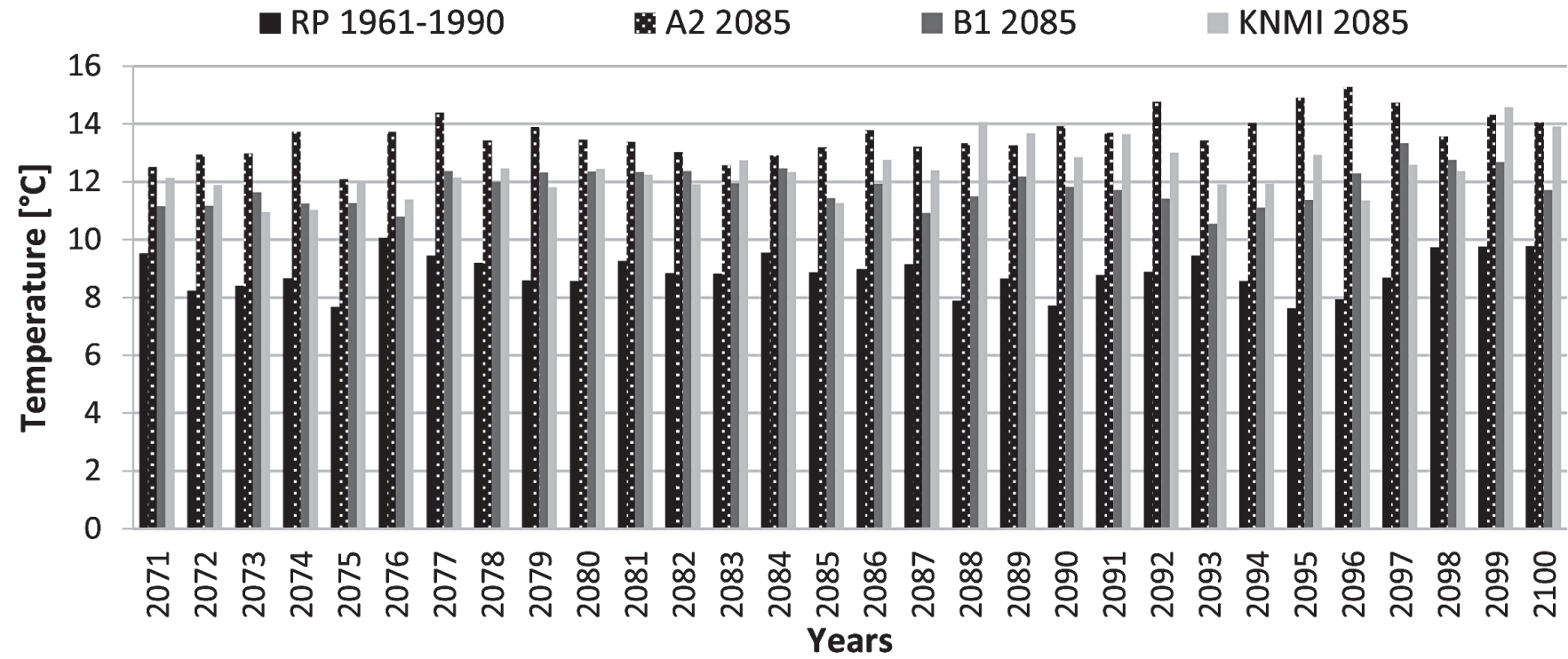

Fig. 3 Comparison of the average annual temperatures within the time horizon 2085 for the SRES A2 and SRES B1 scenarios and the KNMI model with the reference period $(R P)$ 1961-1990.

\section{RESULTS}

The main climate change indicators are precipitation and temperature. The Slovak Hydrometeorological Institute (SHMI) meteorological station nearest to the area of interest in Jakubov is the monitoring station in Malacky. In Fig. 2 and Fig. 3, the course of the temperature modified by the SRES A2 and SRES B1 scenarios and the KNMI model in the time horizon of 2085 (the middle of the time horizon 2071-2100) is shown. This data is compared to the reference period (RP) of 1961-1990. An increase in temperatures compared to the RP can be seen when comparing the average monthly temperatures (Fig. 2). The largest increase in temperature is predicted by the
SRES A2 scenario. On the other hand, the SRES B1 scenario predicts the smallest increase in temperature.

The comparison of the average annual temperatures modified by the SRES A2 and SRES B1 scenario and the KNMI model with the reference period is shown in Fig. 3. The most notable increase in temperature is predicted by the SRES A2 scenario. The SRES B1 scenario predicts a minimal increase in temperature.

Based on the summary in Tab. 3, it can be stated that the SRES A2 scenario predicts a temperature increase of $4.46 \mathrm{C}^{\circ}$ within the next 30 years of the last time horizon (2085), SRES B1 scenario predicts an increase $2.64{ }^{\circ} \mathrm{C}$, and the KNMI model predicts an increase of $3.27^{\circ} \mathrm{C}$ compared to the reference period. 


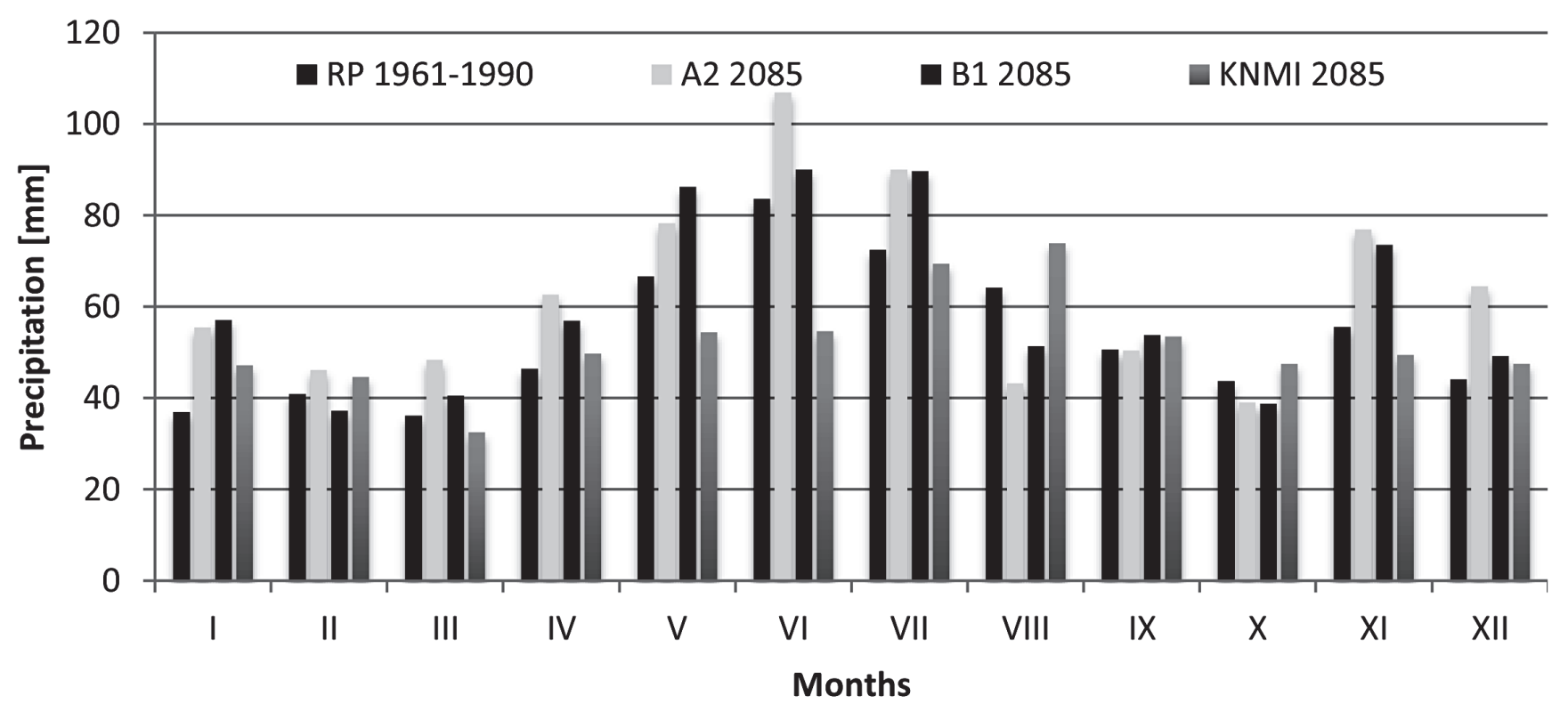

Fig. 4 Comparison of the monthly precipitation within the time horizon 2085 for the SRES A2 and SRES B1 scenarios and the KNMI model with the reference period (RP) 1961-1990.

Tab. 3 Comparison of the average annual temperatures within the time horizon 2085 based on calculations of the data from the SRES A2 and SRES B1 scenarios and the KNMI model data with the reference period (RP) of 1961-1990.

\begin{tabular}{|c|c|c|c|}
\hline RP 1961-1990 & & $\mathbf{T}$ & $\Delta$ \\
\cline { 3 - 4 } \cline { 3 - 4 } $9.16{ }^{\circ} \mathrm{C}$ & SRES A2 & 13.62 & 4.46 \\
\cline { 3 - 4 } & SRES B1 & 11.81 & 2.64 \\
\cline { 2 - 4 } & KNMI & 12.43 & 3.27 \\
\hline
\end{tabular}

Another significant indicator of climate change developments is precipitation. In Fig. 4 and Fig.5, the courses of precipitation are modified by the SRES A2 and SRES B1 scenarios and the KNMI model in the time horizon of 2085 compared with the reference period (RP). From Fig. 4, where the course of monthly precipitation is shown, a noticeable increase in the predicted precipitation from January to July and in November and December can be seen according to the climate scenarios. The KNMI model predicts a decrease in precipitation in nearly all of the months.

The course of the annual precipitation values, as modified and compared with the reference period, can be seen in Fig. 5. The predicted increase in precipitation according to the scenarios and the KNMI model can be clearly seen here also. Table 4 shows a summary of the results, according to which the SRES A2 scenario predicts an increase in precipitation by $120.7 \mathrm{~mm}$, and the SRES B1 scenario by $83.3 \mathrm{~mm}$. On the contrary, the KNMI model predicts a decrease in precipitation by $16.9 \mathrm{~mm}$.

The GLOBAL model is frequently used for simulating soil-water storage. This model was developed by the Slovak Academy of Sciences, namely, by the authors Maječák and Novák (1994).

We used the GLOBAL mathematical model (Maječák and Novák 1994) when assessing the changes caused by climate change in the soil-water storage in the locality of Jakubov. In order to obtain to the soil-water storage predictions, it was necessary to prepare the climate data, which was entered into the model as an upper boundary condition. The data was established by the SRES A2 and SRES B1 cli-
Tab. 4 Comparison of the average annual precipitation based on calculations of the data from the SRES A2 and SRES B1 scenarios and the KNMI model data in time horizon 2085 with the reference period (RP) of 1961-1990.

\begin{tabular}{|c|c|c|c|}
\hline RP 1961-1990 & Climate tools & P & $\Delta$ \\
\hline \multirow{3}{*}{$641.2 \mathrm{~mm}$} & SRES A2 & 761.9 & 120.7 \\
\cline { 2 - 4 } & SRES B1 & 724.5 & 83.3 \\
\cline { 2 - 4 } & KNMI & 624.3 & -16.9 \\
\hline
\end{tabular}

mate scenarios, based on which the CGCM 3.1 global model and the KNMI regional model (Lapin et al., 2009; Lapin, Melo, 2004; Szolgay et al., 2007) run. These models are a more detailed integration of the dynamic equations of atmospheric and oceanic circulations in the network nodes positioned in a grid of $25 \times 25 \mathrm{~km}$. In Slovakia up to $19 \times 10$ nodes exist, and with orography with a good expression of all the mountains which have horizontal dimensions greater than $25 \mathrm{~km}$. The boundary conditions for solving the equations are taken from global model outputs. Global models work with a large number of climatic characteristics, and several of these characteristics have been transferred to a shorter time step. A description of the models together with their detailed characteristics can be found in several works such as Van Meijgaard et al. (2008) and Lapin et al. (2001, 2004, 2006, 2009).

Using input files with the modified climate data, the predictions of changes in the soil-water storage were modeled for a depth of 0 $60 \mathrm{~cm}$ below the ground surface for the time horizon of 2085 for the SRES A2 and SRES B1 scenarios and the KNMI model. They were compared them with the outcomes of the modelling for the reference period (RP) of 1961-1990. The crops studied were spring barley and maize. The final values were then processed in tabular and graphic form for a clearer representation.

The soil-water storage for a depth of $0-60 \mathrm{~cm}$ below the ground surface for the SRES A2 and SRES B1 scenarios and the KNMI model in time horizon 2085, compared with the reference period for the spring barley, is shown in Fig. 6. The graph shows a decrease in soil-wa- 


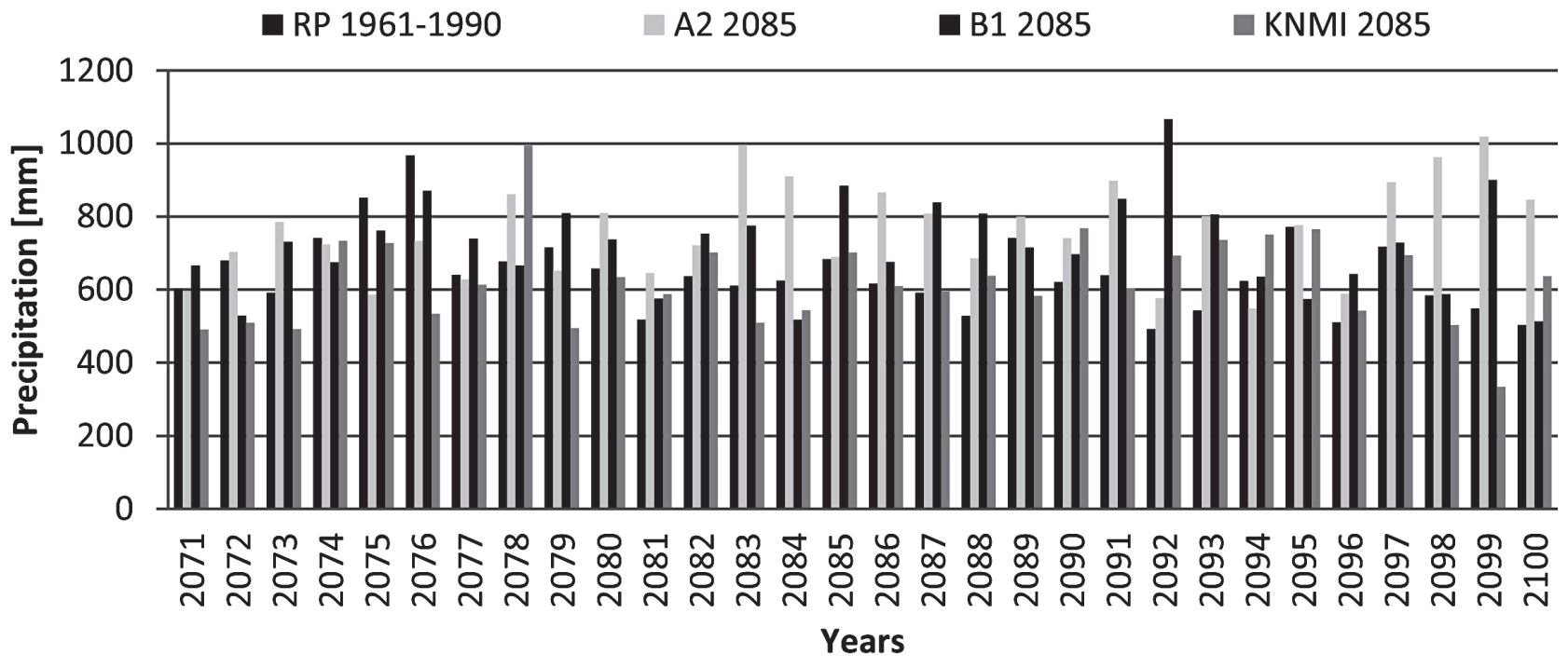

Fig. 5 Comparison of the annual precipitation within the time horizon 2085 for the SRES A2 and SRES B1 scenarios and the KNMI model with the reference period (RP) 1961-1990.

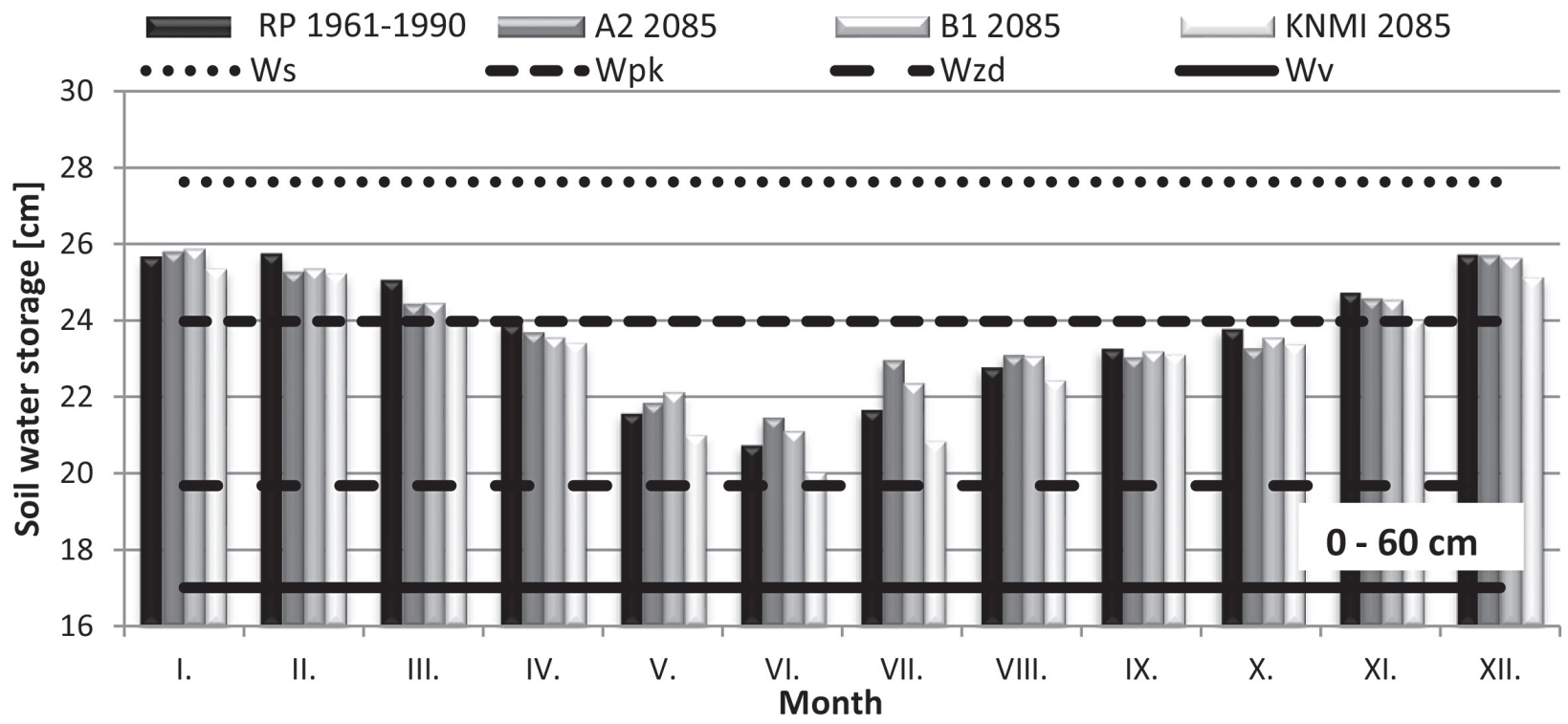

Fig. 6 Comparison of the average monthly soil-water storage calculated with the spring barley crop during vegetation period for a depth of $0-60 \mathrm{~cm}$ below the ground surface in the time horizon 2085 for the SRES A2 and SRES B1 scenarios and the KNMI model with the reference period $(R P)$ and with the hydrolimits of the saturation $\left(W_{s}\right)$, the field water capacity $\left(W_{p k}\right)$, the point of decreased availability $\left(W_{z d}\right)$, and the wilting point $\left(W_{v}\right)$.

ter storage for the KNMI model compared with the reference period (RP). The A2 and B1 scenarios predict a slight increase in soil-water storage in the months of May to August compared with the reference period. The highest soil water storage is expected during the month of January, while a gradual decline can be expected from February. The soil water storage will reach its minimum in June. From July a gradual increase in soil-water storage will occur until the month of December The logical course of the soil-water storage in the summer period is caused by higher temperatures, when the evaporation values are also higher and also the development of the spring barley root system is to be expected. From Fig. 6 it is clear that the soil-water storage is within the range of the field water capacity hydrolimit $\left(\mathrm{W}_{\mathrm{pk}}\right)$ and the point of the decreased availability hydrolimit $\left(\mathrm{W}_{\mathrm{zd}}\right)$. This means that the soil-water storage values are ideal for the favorable development of the vegetation's root systems. In Fig. 6 the soil-water storage is shown for the wilting point hydrolimit $\left(\mathrm{W}_{\mathrm{v}}\right)$, which is critical for the crop. With long-lasting periods of decreases in the soil-water storage, the vegetation will wilt.

The average annual soil-water storage for a depth of $0-60 \mathrm{~cm}$ below the surface is shown in Fig. 7, which compares the 2085 time horizon for the SRES A2 and SRES B1 scenarios and the KNMI model with the RP for the spring barley crop. The graph shows considerable instability over the whole period. Fig. 7 clearly shows that the soil water storage is within the range of the field water capacity hydrolimit $\left(\mathrm{W}_{\mathrm{pk}}\right)$ and the point of the decreased availability hydrolimit $\left(\mathrm{W}_{\mathrm{zd}}\right)$, which represents the ideal conditions for the crop evaluated.

A comparison of the average monthly soil-water storage for the SRES A2 and SRES B1 scenarios and the KNMI model with the RP 


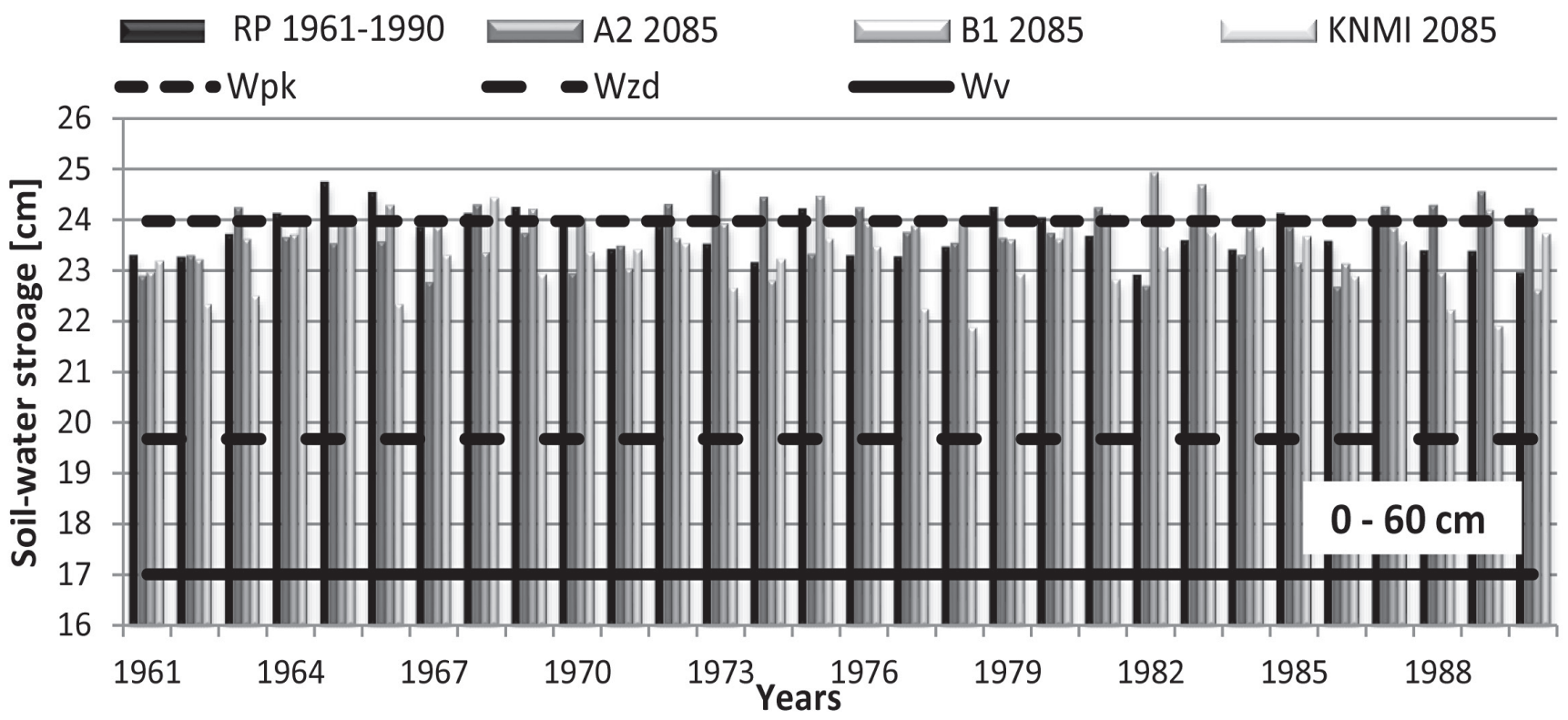

Fig. 7 Comparison of the average annual soil-water storage calculated with the spring barley crop during vegetation period for a depth of $0-60 \mathrm{~cm}$ below the ground surface in the time horizon 2085 for the SRES A2 and SRES B1 scenarios and the KNMI model with the reference period $(R P)$ and with the hydrolimits of the saturation $\left(W_{s}\right)$, the field water capacity $\left(W_{p k}\right)$, the point of decreased availability $\left(W_{z d}\right)$, and the wilting point $\left(W_{v}\right)$.

Tab. 5 Comparison of the average monthly soil-water storage calculated with the spring barley crop based on calculations of the data from the SRES A2 and SRES B1 scenarios and the KNMI model data with the reference period (RP) of 1961-1990.

\begin{tabular}{|c|c|c|c|c|c|c|c|c|c|c|}
\hline \multirow{2}{*}{ Month } & RP & \multicolumn{3}{|c|}{ SRES A2 2085 } & \multicolumn{3}{c|}{ SRES B1 2085 } & \multicolumn{3}{c|}{ KNMI 2085 } \\
\cline { 2 - 11 } & {$[\mathbf{c m}]$} & {$[\mathbf{c m}]$} & $\begin{array}{c}\Delta \\
\text { A2-RO } \\
{[\mathbf{c m}]}\end{array}$ & $\begin{array}{c}\Delta \\
\text { A2-RO } \\
{[\%]}\end{array}$ & $\begin{array}{c}\Delta \\
{[\mathbf{c m}]}\end{array}$ & $\begin{array}{c}\Delta \\
\text { B1-RO } \\
{[\mathbf{c m}]}\end{array}$ & $\begin{array}{c}\Delta \\
\text { B1-RO } \\
{[\%]}\end{array}$ & $\begin{array}{c}\Delta \\
{[\mathbf{c m}]}\end{array}$ & $\begin{array}{c}\Delta \text { KMI-RO } \\
\text { [cm] }\end{array}$ & $\begin{array}{c}\text { KNMI-RO } \\
{[\%]}\end{array}$ \\
\hline I. & 25.68 & 25.80 & 0.12 & 0 & 25.86 & 0.18 & 1 & 25.35 & -0.33 & -1 \\
\hline II. & 25.75 & 25.27 & -0.48 & -2 & 25.35 & -0.41 & -2 & 25.24 & -0.52 & -2 \\
\hline III. & 25.07 & 24.43 & -0.65 & -3 & 24.46 & -0.62 & -2 & 24.10 & -0.97 & -4 \\
\hline IV. & 23.92 & 23.68 & -0.24 & -1 & 23.55 & -0.37 & -2 & 23.41 & -0.51 & -2 \\
\hline V. & 21.59 & 21.84 & 0.25 & 1 & 22.12 & 0.53 & 2 & 21.02 & -0.57 & -3 \\
\hline VI. & 20.75 & 21.45 & 0.70 & 3 & 21.11 & 0.36 & 2 & 20.04 & -0.71 & -3 \\
\hline VII. & 21.68 & 22.96 & 1.27 & 6 & 22.36 & 0.67 & 3 & 20.85 & -0.83 & -4 \\
\hline VIII. & 22.78 & 23.09 & 0.31 & 1 & 23.07 & 0.29 & 1 & 22.44 & -0.34 & -2 \\
\hline IX. & 23.28 & 23.03 & -0.24 & -1 & 23.18 & -0.10 & 0 & 23.11 & -0.17 & -1 \\
\hline X. & 23.79 & 23.26 & -0.53 & -2 & 23.54 & -0.25 & -1 & 23.39 & -0.41 & -2 \\
\hline XI. & 24.74 & 24.57 & -0.16 & -1 & 24.54 & -0.20 & -1 & 24.01 & -0.72 & -3 \\
\hline XII. & 25.72 & 25.70 & -0.02 & 0 & 25.63 & -0.09 & 0 & 25.12 & -0.60 & -2 \\
\hline per year & 23.72 & 23.75 & 0.03 & 0 & 23.72 & 0.00 & 0 & 23.16 & -0.56 & -2 \\
\hline
\end{tabular}

for a depth of $0-60 \mathrm{~cm}$ below the ground surface for the spring barley crop is shown in Tab. 5. The table shows that in the future, both scenarios and the model predict a lower average monthly supply of soil-water storage. The exceptions are the months of January and June to August in both scenarios when they predict increments of the soil-water storage. It can be concluded that during the RP, the average annual soil water storage was $23.72 \mathrm{~cm}$, which is $2 \%$ more than the value that the KNMI model assumed in the time horizon 2085. Both scenarios predict the same course for the soil-water storage at the end of the $21^{\text {st }}$ century as in the RP. The A2 and B1 scenarios are slightly more favorable compared to the RP since it presumes a smaller decrease in the soil water storage than the KNMI model. 


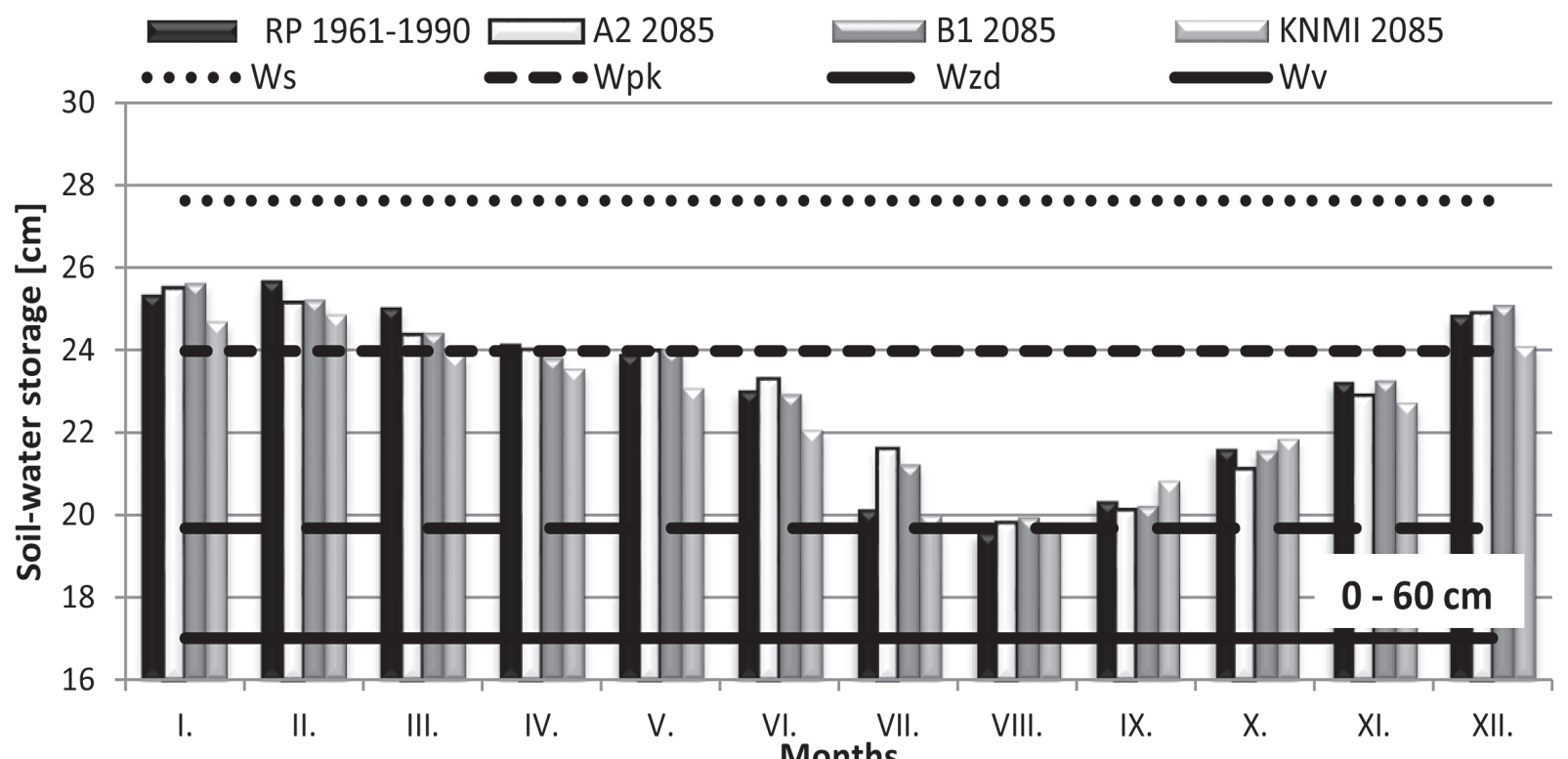

Fig. 8 Comparison of the average monthly soil-water storage calculated with the maize crop during vegetation period for a depth of $0-60 \mathrm{~cm}$ below the ground surface in the time horizon 2085 for the SRES A2 and SRES B1 scenarios and the KNMI model with the reference period $(R P)$ and with the hydrolimits of the saturation $\left(W_{s}\right)$, the field water capacity $\left(W_{p k}\right)$, the point of decreased availability $\left(W_{z d}\right)$ and the wilting point $\left(W_{1}\right)$.

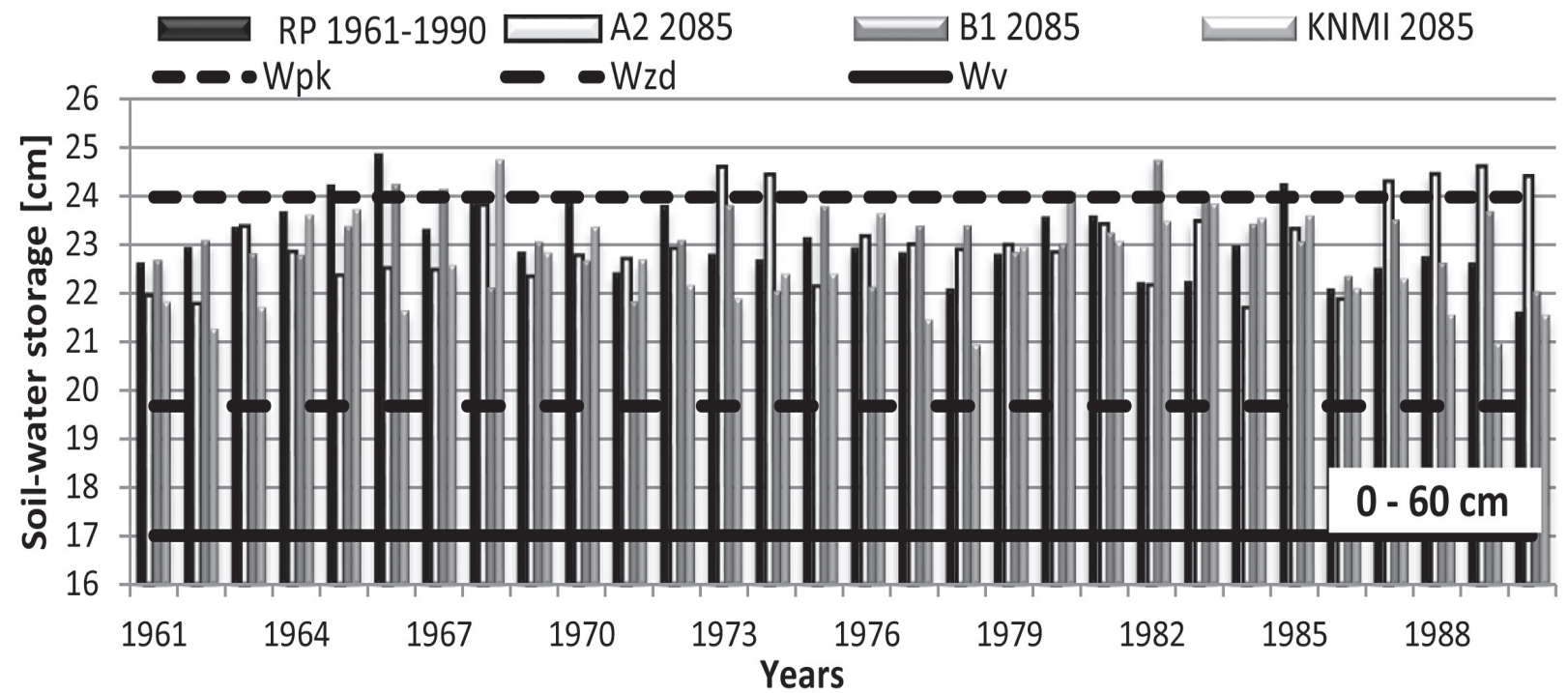

Fig. 9 Comparison of the average annual soil water storage calculated with the maize crop during vegetation period for a depth of 0 - $60 \mathrm{~cm}$ below the ground surface in the time horizon 2085 for the SRES A2 and SRES B1 scenarios and the KNMI model with the reference period $(R P)$ and with the hydrolimits of the saturation $\left(W_{s}\right)$, the field water capacity $\left(W_{p k}\right)$, the point of decreased availability $\left(W_{z d}\right)$ and the wilting point $\left(W_{v}\right)$.

The second crop studied was maize. Its average monthly soil-water storage for a depth of $0-60 \mathrm{~cm}$ below the ground surface is shown in Fig. 8, which compares the soil-water storage for the SRES A2 and SRES B1 scenarios and the KNMI model in the time horizon of 2085 with the RP.

The graph shows a decrease in the soil-water storage compared with the RP except for the months of July and August for the A2 and B1 scenarios and the months of August to October for the KNMI model, when an increase in the soil-water storage is expected. From Fig. 8 it is also clear that from January to April, an increase in the soil-water storage will occur, followed by a gradual decrease from May to August. From the month of September a gradual increase in the soil-water storage can be observed. From Fig. 8 it is clear that the soil-water storage will range between the hydrolimits of the field water capacity $\left(\mathrm{W}_{\mathrm{pk}}\right)$ and the point of decreased availability $\left(\mathrm{W}_{\mathrm{zd}}\right)$.

The average annual soil-water storage of the grass crop for a depth of 0 - $60 \mathrm{~cm}$ below the ground surface and a comparison of the SRES A2 and SRES B1 scenarios and the KNMI model in the time horizon of 2085 with the RP is shown in Fig. 9. The graph clearly shows considerable instability over the whole period. Even when compared with the average soil-water storage it can be stated that the soil-water storage for a depth of $0-60 \mathrm{~cm}$ below the ground surface will range between the field water capacity hydrolimit $\left(\mathrm{W}_{\mathrm{pk}}\right)$ and the point of the decreased availability $\left(\mathrm{W}_{\mathrm{zd}}\right)$. 
Tab. 6 Comparison of the average monthly soil-water storage calculated with the maize crop based on calculations of the data from the SRES A2 and SRES B1 scenarios and the KNMI model data with the reference period (RP) of 1961-1990.

\begin{tabular}{|c|c|c|c|c|c|c|c|c|c|c|}
\hline \multirow{2}{*}{ Month } & RP & \multicolumn{3}{|c|}{ SRES A2 2085 } & \multicolumn{3}{c|}{ SRES B1 2085 } & \multicolumn{3}{|c|}{ KNMI 2085 } \\
\cline { 2 - 11 } & {$[\mathbf{c m}]$} & {$[\mathbf{c m}]$} & $\begin{array}{c}\Delta \\
\mathbf{A 2 - R O} \\
{[\mathbf{c m}]}\end{array}$ & $\begin{array}{c}\Delta \\
\mathbf{A 2 - R O} \\
{[\%]}\end{array}$ & $\begin{array}{c}\Delta \\
{[\mathbf{c m}]}\end{array}$ & $\begin{array}{c}\Delta \\
\text { B1-RO } \\
{[\mathbf{c m}]}\end{array}$ & $\begin{array}{c}\Delta \\
\text { B1-RO } \\
{[\%]}\end{array}$ & $\begin{array}{c}\Delta \\
{[\mathbf{c m}]}\end{array}$ & $\begin{array}{c}\Delta \text { KMI-RO } \\
\text { [cm] }\end{array}$ & $\begin{array}{c}\text { KNMI-RO } \\
{[\%]}\end{array}$ \\
\hline I. & 25.34 & 25.50 & 0.16 & 1 & 25.61 & 0.27 & 1 & 24.68 & -0.66 & -3 \\
\hline II. & 25.68 & 25.15 & -0.54 & -2 & 25.21 & -0.47 & -2 & 24.85 & -0.83 & -3 \\
\hline III. & 25.03 & 24.37 & -0.66 & -3 & 24.41 & -0.62 & -2 & 23.89 & -1.15 & -5 \\
\hline IV. & 24.16 & 24.00 & -0.16 & -1 & 23.81 & -0.35 & -1 & 23.53 & -0.62 & -3 \\
\hline V. & 23.91 & 23.98 & 0.08 & 0 & 23.99 & 0.09 & 0 & 23.06 & -0.84 & -4 \\
\hline VI. & 23.02 & 23.29 & 0.27 & 1 & 22.93 & -0.09 & 0 & 22.05 & -0.97 & -4 \\
\hline VII. & 20.14 & 21.61 & 1.47 & 7 & 21.23 & 1.09 & 5 & 19.97 & -0.17 & -1 \\
\hline VIII. & 19.57 & 19.81 & 0.24 & 1 & 19.95 & 0.38 & 2 & 19.81 & 0.23 & 1 \\
\hline IX. & 20.34 & 20.12 & -0.22 & -1 & 20.22 & -0.12 & -1 & 20.82 & 0.48 & 2 \\
\hline X. & 21.60 & 21.11 & -0.49 & -2 & 21.56 & -0.04 & 0 & 21.84 & 0.23 & 1 \\
\hline XI. & 23.23 & 22.90 & -0.33 & -1 & 23.26 & 0.04 & 0 & 22.71 & -0.52 & -2 \\
\hline XII. & 24.85 & 24.89 & 0.04 & 0 & 25.09 & 0.24 & 1 & 24.09 & -0.77 & -3 \\
\hline per year & 23.06 & 23.05 & -0.01 & 0 & 23.10 & 0.04 & 0 & 22.59 & -0.46 & -2 \\
\hline
\end{tabular}

Tab. 7 Comparison of the average annual soil water storage $(W)$ and average annual precipitation $(P)$ of the reference period $(R P)$ with the data from the SRES A2 and SRES B1 scenarios and the KNMI model for both crops.

\begin{tabular}{|l|c|c|c|c|c|c|c|c|}
\hline \multirow{2}{*}{ Crops } & \multicolumn{2}{|c|}{ RP } & \multicolumn{2}{c|}{ SRES A2 } & \multicolumn{2}{c|}{ SRES B1 } & \multicolumn{2}{c|}{ KNMI } \\
\cline { 2 - 9 } & $\mathbf{W}[\mathbf{m m}]$ & $\mathbf{P}[\mathbf{m m}]$ & $\mathbf{W}[\mathbf{m m}]$ & $\mathbf{P}[\mathbf{m m}]$ & $\mathbf{W}[\mathbf{m m}]$ & $\mathbf{P}[\mathbf{m m}]$ & $\mathbf{W}[\mathbf{m m}]$ & $\mathbf{P}[\mathbf{m m}]$ \\
\hline Spring barley & 237.2 & 509.1 & 237.5 & 601.0 & 237.2 & 643.1 & 231.6 & 530.7 \\
\hline Maize & 230.6 & 509.1 & 230.5 & 601.0 & 231.0 & 643.1 & 225.9 & 530.7 \\
\hline
\end{tabular}

The comparison of the average monthly soil-water storage of the maize crop for the SRES A2 and SRES B1 scenarios and the KNMI model with the RP for a depth of $0-60 \mathrm{~cm}$ below the ground surface is summarized in Table 6. The table shows that in the future, the KNMI model and climate scenarios predict a lower average monthly soil-water storage for most of the year. The exceptions are the months of January and July and August for the A2 scenario and the month of December for the B1 scenario. The exceptions shown by the KNMI model are the months of August to October, when this model predicts an increase in the soil-water storage. Also, it can be noted that during the RP, the average annual soil-water storage was $23.06 \mathrm{~cm}$, which is $2 \%$ higher than the KNMI model prediction during the time horizon of 2085. Both scenarios predict similar movement of the soil-water storage, similar to the reference period at the end of the $21^{\text {st }}$ century.

The comparison of the average annual soil-water storage (W) and the average annual precipitation $(\mathrm{P})$ of the $\mathrm{RP}$ with the data calculated by the SRES A2 and SRES B1 scenarios and the KNMI model for the spring barley and maize is given listed in Table 7, which shows that precipitation affects soil-water storage. If we include the crops in this comparison, we can observe a higher value of the soil-water storage in the maize than in the spring barley crop at the same value of precipitation. This is caused by number of factors, e.g. evaporation from soil surface is greater with the maize crop, because the spring barley crop is a densely sown crop and the soil surface has nearly 90 percent coverage.

\section{CONCLUSION}

There are several predictions of the future developments and consequences of climate change on the environment and humanity. Research shows that the predictions of the changes that are predicted by experts have already begun.

The developmental trends of soil-water storage in the $0-60 \mathrm{~cm}$ deep soil profile are similar to that of the precipitation. That is to be expected, as the moisture in the top soil layer is mostly affected by atmospheric precipitation. In the future, decreases in soil-water storage may be caused by the predicted increases in air temperature, which cause higher values of evapotranspiration and thus a greater extraction of water from the soil.

Based on the results obtained from the KNMI model, it can be concluded that the average annual soil-water storage will decrease. Similar values to the reference period were calculated by the SRES A2 and SRES B1 climate scenarios. By 2100, the KNMI model expects a decrease of $2 \%$ (in both crops) compared to the reference period. While this decrease compared to the reference period is not 
extreme, problems may occur in the uneven distribution of precipitation during the growing season, which may affect developments in the soil-water storage.

The soil-water storage for both crops evaluated (spring barley, maize) ranged between the values of the field water capacity hydrolimit $\left(\mathrm{W}_{\mathrm{PK}}\right)$ and the point of the decreased availability hydrolimit $\left(\mathrm{W}_{\mathrm{ZD}}\right)$ which is a presumption of sufficient water content in soil for the good development of vegetation in the time horizon 2085 .

\section{Acknowledgement}

The authors would especially like to acknowledge the help of the Slovak Hydrometeorological Institute (SHMI) for providing the data and also would like to acknowledge the APVV-0139-10, VEGA 1/0625/15 and VEGA1/0665/15 projects for their assistance. 


\section{REFERENCES}

Group of authors (1992): Rámcový dohovor OSN o zmene klímy [online]. [cit. 25.9.2014]. (United Nations Framework Convention on Climate Change.) http://www1.enviroportal.sk/pdf/dohovory/ newyork0905_1992.pdf

Igaz, D., Tóthová, I., Samuhel, P. (2007): Vyhodnotenie obsahu pôdnej vody s využitím simulačných modelov GLOBAL a DSSAT 4. (Evaluation of soil water content by simulation models GLOBAL and DSSAT 4). Bioclimatology and natural hazards. International Scientific Conference, Pol'ana nad Detvou, Slovakia, September 17 - 20, 2007, ISBN 978-80-228-17-60-8

Lapin, M., Melo, M., Damborská, I. (2001): Scenáre súborov viacerých vzájomne fyzikálne konzistentných klimatických prvkov. In Národný klimatický program SR, zväzok č. 11. Bratislava, MŽP SR, SHMÚ, 2001, s. 5-30 (Files of Scenarios more mutually consistent physical climatic elements. In The National Climate Program, Vol. No. 11. Bratislava, Ministry of Environment, SHI, 2001, p. 5-30)

Lapin, M., Melo, M. (2004): Methods of climate change scenarios projection in Slovakia and selected results. In Journal of Hydrology and Hydromechanics, Vol. 52, 2004, No. 4, p. 224-238.

Lapin, M. et al. (2006): Scenarios of climatic elements daily values for Slovakia until 2100. In: Slovak Meteorological Journal. Vol. 9, Nos. 3-4, 2006. pp. 149-156

Lapin, M. et al. (2009): Possible Impacts of Climate Change on Hydrologic Cycle in Slovakia and Results of Observations. In: 19512007. Biologia, 64/3, 454-459.

Majerčák, J. (2004): Komparácia modelov pohybu vody v systéme atmosféra - rastlinný kryt - pôdny profil - podzemná voda. (Comparation of the Simulation Models OD Water Transport in the Atmosphere-Canopy-Soil Profile-Ground Water System.) In: Zborník z medzinárodnej vedeckej konferencie „Bioklimatologické pracovné dni 2004 - Zmeny podnebia - extrémy počasia organizmy a ekosystémy“, Viničky 23. - 26.8.2004., ISBN 808069-402-8, SPU Nitra 2004, CD, 10 s.
Majerčák, J., Novák, V. (1994): GLOBAL, one-dimensional variable saturated flow model, including root water uptake, evapotranspiration structure, corn yield, interception of precipitations and winter regime calculation. Research Report, 75 pp., Institute of Hydrology, Slovak Academy of Sciences, Bratislava, Slovakia.

Mind'aš, J., Páleník, V., Nejedlík, P. (2011): Dôsledky klimatickej zmeny a možné adaptačné opatrenia $v$ jednotlivých sektoroch. Záverečná správa. In: E F R A - vedecká agentúra pre lesníctvo a ekológiu. Zvolen, Bratislava, November 2011. (The consequences of climate change and possible adaptation measures in different sectors. Final report. In: E F R A - Agency for Forestry Research and ecology.)

Nevřelová, M. (2007): Pričiny a dôsledky klimatických zmien. 2007. (The causes and consequences of climate change.) [online] [cit. 15.1.2014].

http://www.enviro-edu.sk/?page=environmentalne_problemy/priciny_a_dosledky klimatickych_zmien

Pásztorová, Mária. Developments in climate and soil water storage in the locality of Poiplie. In Slovak Journal of Civil Engineering. Vol. 21, No. 1 (2013), s.1-8. ISSN 1210-3896

Szolgay, J. et al. (2007): Vplyv zmeny klímy na odtokový režim na Slovensku. Ostrava: Key Publishing, s.r.o., 2007. ISBN 978-8087071-50-2.160s

Vitková, J., Štekauerová, V., Skalová, J.: Zmeny v zásobách pôdnej vody v dôsledku predpokladanej klimatickej zmeny. (Changes in soil water storage due to possible climate change.) In: Acta hydrologica Slovaca. Vol.14, No. 1 (2013), s.5-9. ISSN 1335-6291.

Van Meijgaard, E et. al. (2008): The KNMI regional atmospheric climate model RACMO version 2.1. KNMI technical report. TR 302. De Bilt, 2008 (http://www.knmi.nl/) 50 pp. 